\title{
Standardy DNV - Kwalifikowanie Technologii Spawania
}

\author{
Standards DNV - Welding Procedure Qualification
}

\section{Streszczenie}

Omówiono zagadnienia dotyczące kwalifikowania technologii spawania stali WELDOX 700 według przepisów DNV. Przedstawiono różnice między wymaganiami EN 15614-1, a wymaganiami przepisów DNV OS-C-401. Zaprezentowano wyniki badań nieniszczących i niszczących.

Słowa kluczowe: technologia spawania; Protokół Kwalifikowania Technologii Spawania; stale WELDOX

\begin{abstract}
Issues related to welding procedure qualification of the WELDOX 700 types of steel according to the DNV rules and standards are described. Differences between EN 15614-1 and DNV OS-C-401 requirements sare provided. Both destructive and non-destructive testing are presented.
\end{abstract}

Keywords: welding technology; Welding Procedure Qualification Record; WELDOX types of steel

\section{Wstęp}

Obecnie znaczna liczba konstrukcji spawanych przeznaczona jest na rynek offshore. Terminem offshore określa się instalacje poszukiwawcze, wydobywcze, przetwórcze i transportujące na pełnym morzu. Konstrukcje te służą do eksploatacji złóż minerałów znajdujących się pod dnem morza. Pojęcie to obejmuje również jednostki do obsługi konstrukcji na pełnym morzu. Konstrukcje tego rodzaju tworzą bardzo liczną grupę rozwiązań, które znacznie się od siebie różnią, każda z nich ma inne przeznaczenie i różnorodne środowiska pracy. Ponadto konstrukcje typu offshore muszą być niezawodne $w$ trakcie eksploatacji. Awaria platformy najczęściej kończy się katastrofą ekologiczną i śmiercią załogi. Zaistniałe awarie miały ogromny wpływ na zaostrzenie przepisów w celu eliminacji takich katastrof w przyszłości. Dlatego też firmy wykonujące tego typu instalacje musiały opracować technologie spawania wg przepisów DNV. Przepisy stosowane przez DNV i związane z nimi dokumenty są regularnie aktualizowane, tak by odzwierciedlały doświadczenie operacyjne, a także postęp rozwoju technologii. Wymagania opracowane przez Towarzystwo Det Norske Veritas (DNV) powstały celem ustalenie standardów zapewniających właściwe bezpieczeństwo i efektywne wykorzystanie nakładów w przemyśle produkującym na rynek offshore. Obejmują one wszystkie etapy powstawania konstrukcji, począwszy od projektowania, poprzez wytwarzanie, kończąc na odbiorze, w tym również standardów procedury kwalifikowania technologii spawania wg. DNV OS C-401 [1].

Do kwalifikowania technologii spawania oraz zastosowania w dalszej produkcji zastosowano stal WELDOX 700. Stale typu WELDOX zaliczane są do grupy stali konstrukcyjnych niskostopowych o wysokiej wytrzymałości mechanicznej, umacnianych wydzielinowo lub ulepszanych cieplnie. Stale o podwyższonej wytrzymałości można zaliczyć do bardzo szerokiej grupy stali HSS i AHSS (Adveced Hight Strenght
Steel). Stale wykazujące granicę plastyczności na poziomie powyżej $550 \mathrm{MPa}$ najczęściej można zaliczyć do stali CP (complex phase) lub stali martenzytycznych. Ich struktura składa się z drobnoziarnistego ferrytu, umocnionego dyspersyjnymi wydzieleniami węglików, azotków i węglikoazotków tytanu, niobu, wanadu i molibdenu [2,3].

\section{Porównanie wymagań normy EN 15614-1 z wymaganiami przepisów DNV 0S-C-401}

Kwalifikowanie technologii spawania według DNVOS-C401 różni się od normy EN ISO 15614-1 zakresem badań mechanicznych (w zasadzie udarnością). W zakresie podstawowym występują 4 zestawy próbek (po 3 w zestawie), pobrane $2 \mathrm{~mm}$ pod powierzchnią blachy od strony lica, z karbem po jednym w spoinie i w linii przejścia spoina - materiał rodzimy oraz po 2 w strefie wpływu ciepła. Dodatkowo dla złączy o grubości ponad $50 \mathrm{~mm}$ dochodzą jeszcze kolejne 2 zestawy pobrane $\mathrm{w}$ warstwie przetopowej, jeden z karbem w osi spoiny, drugi z karbem na linii przejścia spoina - materiał rodzimy. W przypadku kwalifikowania technologii spawania według DNV-OS-C401 w prosty sposób rozszerzono je o wymagania EN ISO 15614-1, gdzie dla próby udarności wymagane są 2 zestawy po 3 próbki [5].

\section{Część praktyczna}

Przed rozpoczęciem prac spawalniczych opracowano wstępną instrukcję technologiczną spawania (pWPS). Następnie przygotowano płytę próbną z materiału WELDOX 700 do kwalifikowania technologii spawania. Materiał podstawowy do wykonania złącza próbnego został dobrany

Mgr inż. Maciej Gątarek - PGE Górnictwo i Energetyka Konwencjonalna SA, Bełchatów; dr hab. inż. prof. IS Jacek Słania - Instytut Spawalnictwa.

Autor korespondencyjny/Corresponding author: gatarekmaciej@gmail.com 
Tablica I. Porównanie zakresu badań mechanicznych dla złączy czołowych wg EN ISO 15614-1 oraz DNV-OS-C-401

Table I. A comparison of the scope of mechanical tests for butt joints according to the EN ISO 15614-1 and DNV-OS-C-401 standards

\begin{tabular}{|c|c|c|c|}
\hline Rodzaj badań & EN ISO 15614-1 & DNV-OS-C-401 & Pełen zakres \\
\hline Próba rozciągania & 2 próbki & 2 próbki & 2 próbki \\
\hline Próba zginania & $\begin{array}{c}\text { po } 2 \text { próbki - rozciąganie } \\
\text { od strony lica i grani }\end{array}$ & $\begin{array}{c}\text { po } 1 \text { próbce - rozciąganie } \\
\text { od strony lica i grani') }\end{array}$ & $\begin{array}{c}\text { po } 2 \text { próbki - rozciąganie } \\
\text { od strony lica i granil) }\end{array}$ \\
\hline Próba udarności & 2 zestawy po 3 próbki & 4 zestawy po 3 próbki²) & 4 zestawy po 3 próbki²) \\
\hline Badania makroskopowe & 1 próbka & 1 próbka & 2 próbki \\
\hline Pomiar twardości & 1 próbka & 1 próbka & 1 próbka \\
\hline
\end{tabular}

wg standardu DNV-OS-B10. Przygotowanie próbki do uzyskania technologii spawania zostało podzielone na etapy: Pierwszym etapem było wycięcie próbki z blachy arkusza o wymiarach 2000 x $10000 \mathrm{~mm}$ za pomocą przecinarki do cięcia tlenowego. Następnym etapem było przygotowanie brzegów próbki do spawania. Brzegi zostały zukosowane za pomocą palnika tlenowego zgodnie z pWPS.

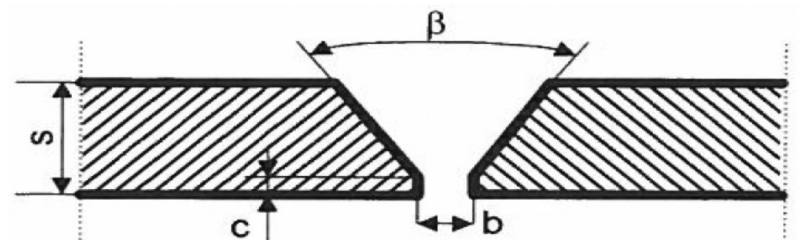

Rys. 1. Przygotowanie złącza $s=40 \mathrm{~mm} ; b=1 \div 3 \mathrm{~mm} ; c=0 \div 1 \mathrm{~mm}$; $\beta=45^{\circ}$

Fig. 1. Preparation of the joint $\mathrm{s}=40 \mathrm{~mm} ; \mathrm{b}=1 \div 3 \mathrm{~mm} ; \mathrm{c}=0 \div 1 \mathrm{~mm}$; $\beta=45^{\circ}$

Kolejnym etapem było oczyszczenie brzegów do metalicznego połysku na odległość $10 \mathrm{~mm}$ od ścianki rowka. Po oczyszczeniu rowka zostały wykonane spoiny sczepne - na łączeniu blach wybiegowych z blachami wchodzącymi w skład złącza. Spawanie płyty próbnej do kwalifikowania technologii spawania ze stali WELDOX 700 zostało przeprowadzone w pozycji naściennej (PC).

Po zakończonym spawaniu przeprowadzono badania wizualne próbki złącza zgodnie z PN EN ISO 17630. Ocenę przeprowadzono wg PN EN ISO 5817, poziom, jakości B. Badane złącze oceniono z wynikiem pozytywnym, nie stwierdzono obecności powierzchniowych niezgodności spawalniczych.

W celu wykrycia pęknięć powierzchniowych przeprowadzono badania magnetyczno- proszkowe. Badania przeprowadzono zgodnie z PN EN ISO 17638 oraz PN EN ISO 5817. Kryteria akceptacji 2x wg PN EN ISO 23278. Badane złącze oceniono z wynikiem pozytywnym, nie stwierdzono pęknięć powierzchniowych.

W celu wykrycia objętościowych niezgodności spawalniczych przeprowadzono badania ultradźwiękowe za pomocą

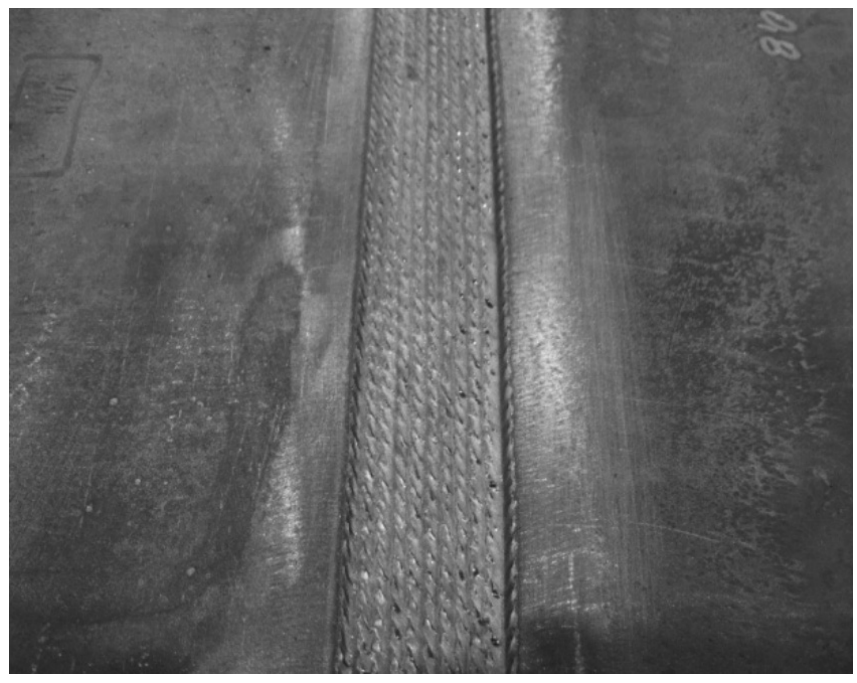

Rys. 2. Płyta próbna po zakończeniu spawania

Fig. 2. A sample plate after finishing welding

Tablica II. Wyniki statycznej próby rozciągania

Table II. Tensil strength results

\begin{tabular}{|c|c|c|c|c|c|c|c|c|c|c|c|c|c|}
\hline \multicolumn{5}{|c|}{ Wymiary próbek } & \multicolumn{9}{|c|}{ Wyniki próby } \\
\hline \multirow[t]{2}{*}{$\begin{array}{l}\stackrel{\mathscr{U}}{\bar{N}} \\
\text { N } \\
\tilde{\pi} \\
\stackrel{N}{N} \\
0\end{array}$} & 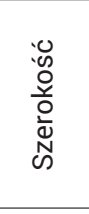 & $\begin{array}{l}0 \\
\text { On } \\
0 \\
\text { 은 } \\
\text { ㄴ }\end{array}$ & $\begin{array}{l}\frac{0}{0} \\
\frac{1}{N} \\
\frac{1}{2}\end{array}$ & 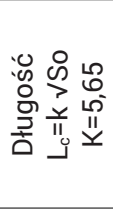 & 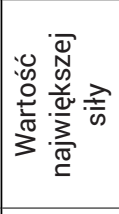 & 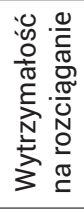 & $\begin{array}{l}\text { i } \\
\text { O } \\
\text { O } \\
\text { 吉 }\end{array}$ & 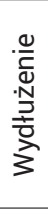 & 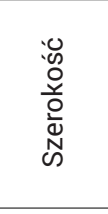 & 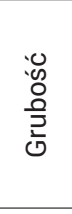 & $\begin{array}{l}\frac{0}{0} \\
\frac{0}{2} \\
\frac{0}{2}\end{array}$ & 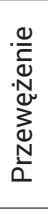 & \multirow[t]{2}{*}{ 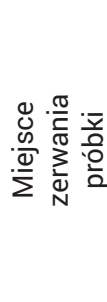 } \\
\hline & $\begin{array}{c}\emptyset, \mathrm{b}, \mathrm{d} \\
\mathrm{mm}\end{array}$ & $\begin{array}{c}\mathrm{a} \\
\mathrm{mm}\end{array}$ & $\begin{array}{c}\mathrm{S}_{0} \\
\mathrm{~mm}^{2}\end{array}$ & $\begin{array}{c}\mathrm{L}_{0} \\
\mathrm{Mm}\end{array}$ & $\begin{array}{c}F_{m} \\
{[k N]}\end{array}$ & $\begin{array}{c}\mathrm{Rm} \\
{[\mathrm{MP}]}\end{array}$ & $\begin{array}{c}\mathrm{L}_{0} \\
\mathrm{~mm}\end{array}$ & $\begin{array}{l}A_{0} \\
\%\end{array}$ & $\begin{array}{c}\varnothing, \mathrm{b}, \mathrm{d} \\
\mathrm{mm}\end{array}$ & $\begin{array}{c}\mathrm{a} \\
\mathrm{mm}\end{array}$ & $\begin{array}{c}\mathrm{S}_{0} \\
\mathrm{~mm}^{2}\end{array}$ & $\begin{array}{l}Z \\
\%\end{array}$ & \\
\hline $27-4 / 1-1$ & 24,98 & 24,85 & 620,8 & - & 515000 & 830 & - & & & & & & $\begin{array}{c}\text { W } \\
\text { spoinie }\end{array}$ \\
\hline $27-4 / 1-2$ & 25,09 & 24,3 & 609,7 & - & 509000 & 835 & - & & & & - & $\cdot$ & $\begin{array}{c}\text { W } \\
\text { spoinie }\end{array}$ \\
\hline $27-4 / 2-1$ & 25,06 & 24,9 & 624,0 & - & 521000 & 835 & - & - & - & - & - & - & $\begin{array}{c}\text { W } \\
\text { spoinie }\end{array}$ \\
\hline $27-4 / 2-2$ & 25,14 & 24,3 & 610,9 & - & 514000 & 841 & - & - & - & - & - & - & $\begin{array}{c}\text { W } \\
\text { spoinie }\end{array}$ \\
\hline
\end{tabular}


aparatury badawczej KRAUTKRAMER USM 35SX używając głowic MB4S, MWB60-4, MWB70-4. Badania przeprowadzono zgodnie z normą PN EN 17640 wg poziomu badań klasy B. Natomiast kryteria akceptacji dokonano wg PN EN 11666, poziom akceptacji 2. Badane złącze oceniono z wynikiem pozytywnym, nie stwierdzono obecności objętościowych niezgodności spawalniczych.

Po zakończonych badaniach nieniszczących rozpoczęto badania niszczące. Próby rozciągania przeprowadzono na maszynie wytrzymałościowej Roel Zwick Z1000. Wg PN-EN IOS 4136 w temperaturze $22^{\circ} \mathrm{C}$.

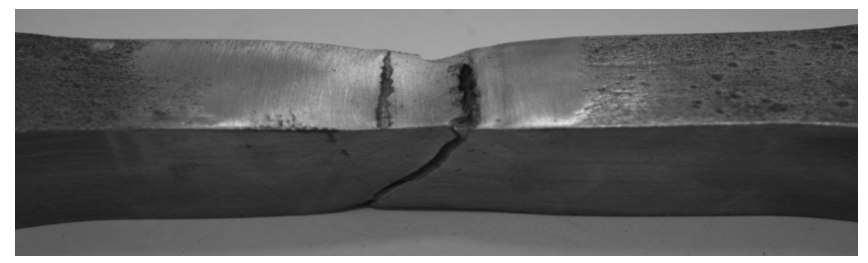

Rys. 3. Próbka po próbie rozciągania Fig. 3. A sample after tensile testing

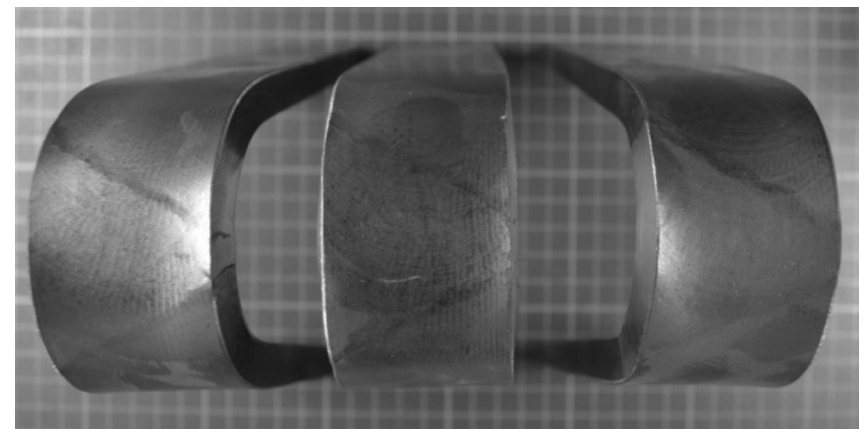

Rys. 4. Próbki po próbie zginania z rozciąganiem od strony lica Fig. 4. Samples after bend testing with tensile stress from the face side

Próbę zginania wykonano wg PN EN ISO 5173 w temperaturze $23^{\circ} \mathrm{C}$. Na rysunku 4 przedstawiono wyniki próby.

Próbę udarności przeprowadzono na młocie Charpy'ego w temperaturze $-60^{\circ} \mathrm{C}$ o początkowej energii łamania wynoszącego 300J. Pobrano i zbadano 18 próbek wg PN EN 148-1. Wymiary próbek 10x10x55 mm każda z karbem $2 \mathrm{~mm}$ typu "V".

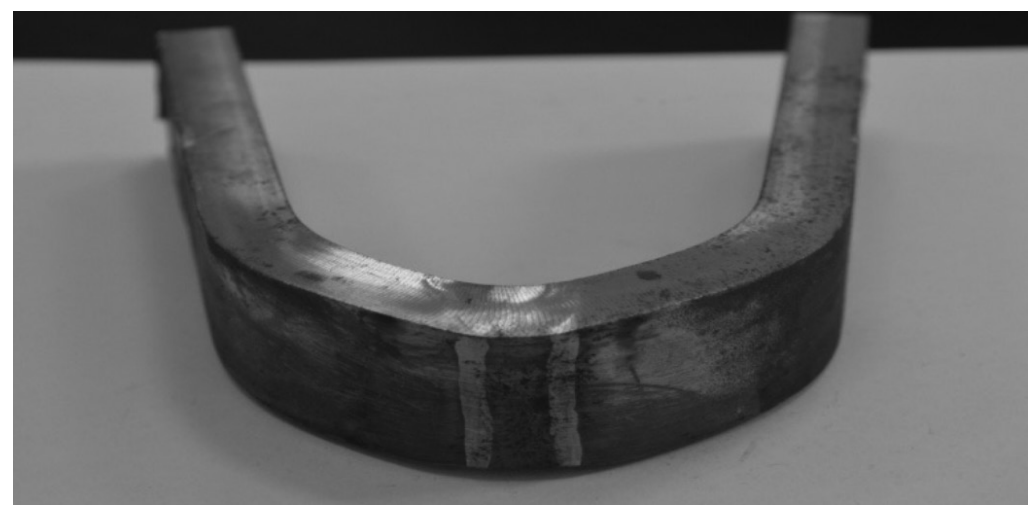

Rys. 5. Próbka po próbie zginania z rozciąganiem od strony grani

Fig. 5. Samples after bend testing with tensile stress from the root side

Tablica III. Protokół z próby zginania

Table III. Bend testing results

\begin{tabular}{|c|c|c|c|c|c|c|c|c|c|c|c|c|c|c|c|}
\hline \multicolumn{7}{|c|}{ Wymiary próbek } & \multicolumn{9}{|c|}{ Wyniki próby } \\
\hline \multirow[t]{2}{*}{$\begin{array}{l}\frac{\mathscr{U}}{\bar{N}} \\
\mathbb{N} \\
\mathbb{\pi} \\
\stackrel{N}{N} \\
0\end{array}$} & \multirow{2}{*}{ 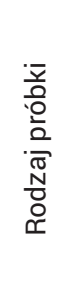 } & 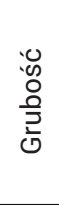 & 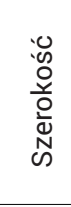 & 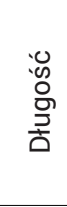 & 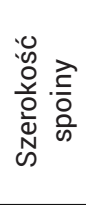 & 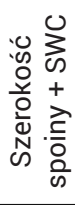 & 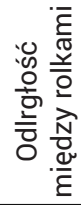 & 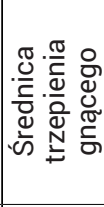 & 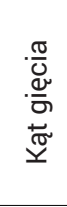 & 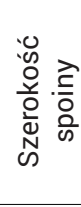 & 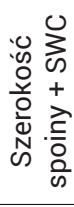 & 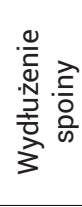 & 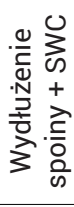 & \multirow{2}{*}{ 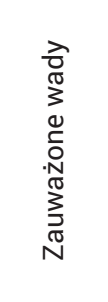 } & \multirow[t]{2}{*}{ 版 } \\
\hline & & $\underset{\mathrm{mm}}{\mathrm{a}}$ & $\underset{\mathrm{mm}}{\mathrm{b}}$ & $\begin{array}{c}\mathrm{Lt}_{\mathrm{t}} \\
\mathrm{mm}\end{array}$ & $\mathrm{mm}$ & $\mathrm{mm}$ & $\begin{array}{c}\mathrm{I} \\
\mathrm{mm}\end{array}$ & $\underset{\mathrm{mm}}{\mathrm{d}}$ & $\begin{array}{l}a \\
0\end{array}$ & $\mathrm{~mm}$ & $\mathrm{~mm}$ & $\%$ & $\%$ & & \\
\hline 27.5/1PC & SBB & 40 & 10 & 300 & - & - & 72 & 50 & 180 & & & & & 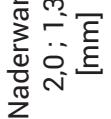 & - \\
\hline $27.5 / 2 P C$ & SBB & 40 & 10 & 300 & & - & 72 & 50 & 180 & 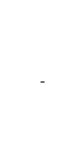 & - & - & - & 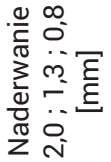 & - \\
\hline 27.5/3/PC & SBB & 40 & 10 & 300 & - & - & 72 & 50 & 180 & - & - & - & - & 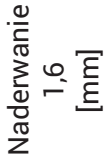 & - \\
\hline 27.5/4PC & SBB & 40 & 10 & 300 & & - & 72 & 50 & 180 & - & - & - & & 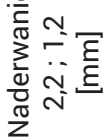 & - \\
\hline
\end{tabular}


Tablica IV. Wyniki próby udarności

Table IV. Impact test results

\begin{tabular}{|c|c|c|c|c|c|c|c|c|c|c|}
\hline & & Wymia & próbek & & & & & Nyniki prób & & \\
\hline.$\stackrel{\varrho}{=}$ & & & $\begin{array}{l}\text { miary przekr } \\
\text { miejscu kar }\end{array}$ & & & $\begin{array}{c}\text { Średnia } \\
\text { praca }\end{array}$ & & & & $\begin{array}{l}\bar{d} \\
\text { on } \\
\stackrel{0}{=}\end{array}$ \\
\hline $\begin{array}{l}\text { N } \\
\mathbb{N} \\
\bar{N} \\
0\end{array}$ & $\begin{array}{l}\text { i kształt } \\
\text { karbu }\end{array}$ & Grubość & Szerokość & Przerój & łamania & $\begin{array}{c}\text { z } 3 \\
\text { pomiarów }\end{array}$ & Suantiose & $\begin{array}{l}\text { Miejsce } \\
\text { przełomu }\end{array}$ & $\begin{array}{l}\text { Rodzaj } \\
\text { przełomu }\end{array}$ & 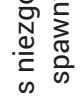 \\
\hline & & $\mathrm{mm}$ & $\mathrm{mm}$ & $\mathrm{cm}^{2}$ & $\mathrm{~J}$ & $J$ & $\mathrm{~J} / \mathrm{cm}^{2}$ & & & $\overline{0}$ \\
\hline $\begin{array}{l}\text { Spoina } \\
\text { (WM) } 1\end{array}$ & $\mathrm{KV}_{2}$ & 10 & 8 & 0,8 & 104,0 & 104,0 & 130,0 & - & & - \\
\hline $\begin{array}{l}\text { Spoina } \\
\text { (WM) } 2\end{array}$ & $\mathrm{KV}_{2}$ & 10 & 8 & 0,8 & 98,7 & 104,0 & 123,4 & - & & - \\
\hline $\begin{array}{l}\text { Spoina } \\
\text { (WM) } 3\end{array}$ & $\mathrm{KV}_{2}$ & 10 & 8 & 0,8 & 109,2 & 104,0 & 136,4 & - & & - \\
\hline $\begin{array}{l}\text { Linia } \\
\text { stopienia } \\
(F L) 1\end{array}$ & $\mathrm{KV}_{2}$ & 10 & 8 & 0,8 & 62,3 & 108,0 & 77,9 & - & & - \\
\hline $\begin{array}{c}\text { Linia } \\
\text { stopienia } \\
(\mathrm{FL}) 2\end{array}$ & $\mathrm{KV}_{2}$ & 10 & 8 & 0,8 & 105,0 & 108,0 & 131,3 & - & & - \\
\hline $\begin{array}{c}\text { Linia } \\
\text { stopienia } \\
(\mathrm{FL}) 3\end{array}$ & $\mathrm{KV}_{2}$ & 10 & 8 & 0,8 & 156,6 & 108,0 & 195,8 & - & & - \\
\hline $\begin{array}{l}\text { Linia } \\
\text { stopienia } \\
+2 \mathrm{~mm} \\
\mathrm{Fl}+2 / 1\end{array}$ & $\mathrm{KV}_{2}$ & 10 & 8 & 0,8 & 160,1 & 108,4 & 200,1 & - & & - \\
\hline $\begin{array}{l}\text { Linia } \\
\text { stopienia } \\
+2 \mathrm{~mm} \\
\mathrm{Fl}+2 / 2 \\
\end{array}$ & $\mathrm{KV}_{2}$ & 10 & 8 & 0,8 & 167,4 & 108,4 & 209,3 & - & & - \\
\hline $\begin{array}{l}\text { Linia } \\
\text { stopienia } \\
+2 \mathrm{~mm} \\
\mathrm{Fl}+2 / 3\end{array}$ & $\mathrm{KV}_{2}$ & 10 & 8 & 0,8 & 225,6 & 108,4 & 282,0 & - & 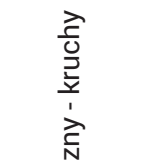 & - \\
\hline $\begin{array}{l}\text { Linia } \\
\text { stopienia } \\
+2 \mathrm{~mm} \\
\mathrm{Fl}+5 / 1\end{array}$ & $\mathrm{KV}_{2}$ & 10 & 8 & 0,8 & 219,6 & 205,1 & 274,5 & - & 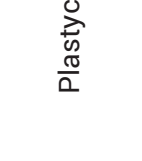 & - \\
\hline $\begin{array}{l}\text { Linia } \\
\text { stopienia } \\
+2 \mathrm{~mm} \\
\mathrm{Fl}+5 / 2\end{array}$ & $\mathrm{KV}_{2}$ & 10 & 8 & 0,8 & 189,0 & 205,1 & 236,3 & - & & - \\
\hline $\begin{array}{l}\text { Linia } \\
\text { stopienia } \\
+2 \mathrm{~mm} \\
\mathrm{Fl}+5 / 3\end{array}$ & $\mathrm{KV}_{2}$ & 10 & 8 & 0,8 & 206,6 & 205,1 & 258,3 & - & & - \\
\hline $\begin{array}{l}\text { Spoina } \\
\text { przetop } \\
\text { RA-WL1 }\end{array}$ & $\mathrm{KV}_{2}$ & 10 & 8 & 0,8 & 86,3 & 86,8 & 107,9 & - & & - \\
\hline $\begin{array}{l}\text { Spoina } \\
\text { przetop } \\
\text { RA-WL2 }\end{array}$ & $\mathrm{KV}_{2}$ & 10 & 8 & 0,8 & 68,7 & 86,8 & 85,9 & - & & - \\
\hline $\begin{array}{l}\text { Spoina } \\
\text { przetop } \\
\text { RA-WL3 }\end{array}$ & $\mathrm{KV}_{2}$ & 10 & 8 & 0,8 & 105,5 & 86,8 & 131,9 & - & & - \\
\hline $\begin{array}{l}\text { SWC } \\
\text { przetop } \\
\text { FL } 1\end{array}$ & $\mathrm{KV}_{2}$ & 10 & 8 & 0,8 & 56,1 & 65,7 & 70,1 & - & & - \\
\hline
\end{tabular}


Tablica IV. Cd. Wyniki próby udarności

Table IV. Cont. Impact test results

\begin{tabular}{|c|c|c|c|c|c|c|c|c|c|c|}
\hline \multicolumn{6}{|c|}{ Wymiary próbek } & \multicolumn{5}{|c|}{ Wyniki próby } \\
\hline \multirow{3}{*}{ 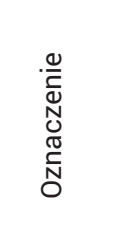 } & \multirow{3}{*}{$\begin{array}{c}\text { Rodzaj } \\
\text { i kształt } \\
\text { karbu }\end{array}$} & \multicolumn{3}{|c|}{$\begin{array}{l}\text { Wymiary przekroju } \\
\text { w miejscu karbu }\end{array}$} & \multirow{2}{*}{$\begin{array}{c}\text { Praca } \\
\text { tamania }\end{array}$} & \multirow{2}{*}{$\begin{array}{c}\text { Średnia } \\
\text { praca } \\
\text { tamania } \\
\text { z } 3 \\
\text { pomiarów }\end{array}$} & \multirow{2}{*}{ Udarność } & \multirow{3}{*}{$\begin{array}{l}\text { Miejsce } \\
\text { przełomu }\end{array}$} & \multirow{3}{*}{$\begin{array}{c}\text { Rodzaj } \\
\text { przełomu }\end{array}$} & \multirow{3}{*}{ 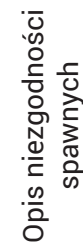 } \\
\hline & & Grubość & Szerokość & Przerój & & & & & & \\
\hline & & $\mathrm{mm}$ & $\mathrm{mm}$ & $\mathrm{cm}^{2}$ & $\mathrm{~J}$ & $J$ & $\mathrm{~J} / \mathrm{cm}^{2}$ & & & \\
\hline $\begin{array}{c}\text { SWC } \\
\text { przetop } \\
\text { FL } 2\end{array}$ & $\mathrm{KV}_{2}$ & 10 & 8 & 0,8 & 74,0 & 65,7 & 92,5 & - & $\begin{array}{l}\frac{\vec{c}}{0} \\
\frac{0}{2} \\
\frac{1}{1}\end{array}$ & - \\
\hline $\begin{array}{c}\text { SWC } \\
\text { przetop } \\
\text { FL3 }\end{array}$ & $\mathrm{KV}_{2}$ & 10 & 8 & 0,8 & 67,0 & 65,7 & 83,8 & - & 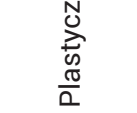 & - \\
\hline
\end{tabular}

Pomiar twardości wykonano wg. normy PN-EN ISO 6507-

1 na twardościomierzu typu: HPO-250 w temperaturze $24^{\circ} \mathrm{C}$.

Badania makroskopowe przeprowadzono wg PN EN 1321.
Natomiast kryteria akceptacji przyjęto wg PN EN 5817. Do trawienia próbek użyto odczynnika „Wagapow”. Obserwacji próbek dokonano przy powiększeniu 1:1.

Tablica V. Wyniki pomiaru twardości

Table V. Hardness testing results

\begin{tabular}{|c|c|c|c|c|c|c|c|c|c|c|c|c|}
\hline \multirow{3}{*}{ 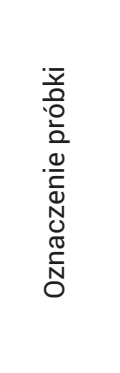 } & \multicolumn{6}{|c|}{ Metoda pomiaru } & \multicolumn{6}{|c|}{ Wyniki pomiaru } \\
\hline & \multicolumn{2}{|c|}{$\begin{array}{c}\text { Brinella HB } \\
\text { wg PN-En ISO 6506-1 }\end{array}$} & \multicolumn{2}{|c|}{$\begin{array}{c}\text { Vickersa HV } \\
\text { wg PN-EN ISO 6507-1 }\end{array}$} & \multicolumn{2}{|c|}{$\begin{array}{c}\text { Rockwella HR } \\
\text { wg PN-EN ISO 6506-1 }\end{array}$} & \multicolumn{5}{|c|}{ Twardość w punktach pomiarowych złącza: } & \multirow{2}{*}{ 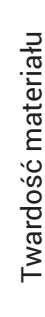 } \\
\hline & 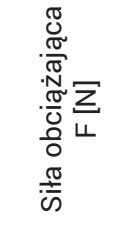 & 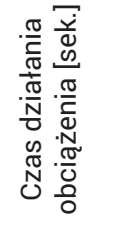 & 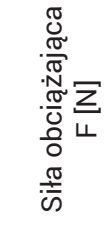 & 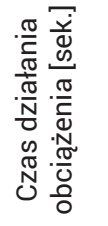 & 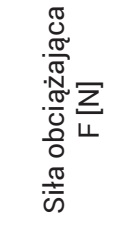 & 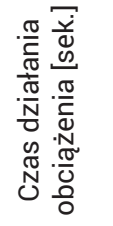 & MP & SWC & S & SWC & MP & \\
\hline \multirow{3}{*}{$\begin{array}{c}\text { 154-27,7 } \\
\text { górna } \\
\text { linia }\end{array}$} & \multicolumn{2}{|c|}{-} & 98 & 20 & \multicolumn{2}{|c|}{-} & 254 & 279 & 292 & 279 & 256 & - \\
\hline & \multicolumn{2}{|c|}{-} & 98 & 20 & \multicolumn{2}{|c|}{ - } & 258 & 285 & 289 & 383 & 260 & - \\
\hline & \multicolumn{2}{|c|}{-} & 98 & 20 & \multicolumn{2}{|c|}{-} & 251 & 281 & 302 & 276 & 266 & - \\
\hline \multirow{3}{*}{$\begin{array}{c}\text { 154-27,7 } \\
\text { górna } \\
\text { linia }\end{array}$} & \multicolumn{2}{|c|}{-} & 98 & 20 & \multicolumn{2}{|c|}{-} & 256 & 281 & 290 & 281 & 254 & - \\
\hline & \multicolumn{2}{|c|}{-} & 98 & 20 & \multicolumn{2}{|c|}{-} & 268 & 283 & 292 & 272 & 268 & - \\
\hline & \multicolumn{2}{|c|}{-} & 98 & 20 & \multicolumn{2}{|c|}{-} & 256 & 294 & 294 & 279 & 259 & - \\
\hline
\end{tabular}

\begin{tabular}{|l|l|l|}
\hline Oznaczenie: & $\begin{array}{l}\text { PC PN-EN 1321-A-E-3.1- } \\
\text { 3.1/Wagapow } \\
\text { A- badanie makroskopowe } \\
\text { powierzchni probki } \\
\text { E-wytrawiona }\end{array}$ \\
\hline $\begin{array}{l}\text { Odczynnik } \\
\text { trawiagcy: }\end{array}$ & Wagapow \\
\hline Powiększenie: & $1,25: 1$ \\
\hline Opis / ocena: & B \\
\hline
\end{tabular}

Rys. 6. Wynik z badań makroskopowych złącza spawanego

Fig. 6. Macroscopic examination result of the welded joint

\section{Wnioski}

W publikacji przedstawiono kwalifikowanie technologii spawania stali WELDOX 700 wg przepisów DNV w celu rozszerzenia działalności firmy o konstrukcje offshore. Przeprowadzone wszystkie czynności związane z uznaniem technologii spawania pozwoliły na sformułowanie podsumowania: 
- Badania nieniszczące - badania wizualne, badania magnetyczno-proszkowe i badania ultradźwiękowe przeprowadzone na płycie próbnej nie wykazały żadnych niezgodności spawalniczych. Spoiny cechowały się odpowiednim kształtem geometrycznym.

- Próba rozciągania została przeprowadzona w temperaturze pokojowej $22{ }^{\circ} \mathrm{C}$. Badanie wykazało wysoką wytrzymałość na rozciąganie złącza spawanego. Wymagana wytrzymałość na rozciąganie dla stali WELDOX 700 wynosi (Re 770 do 940MPa). Wynik próby złącza spawanego wyniósł około 830MPa. Miejsce zerwania próbek następowało w spoinie.

- Próbki były zginane od strony lica i od strony grani, a kąt gięcia wynosił 180. Próbki nie wykazały naderwań ani pęknięć, co dowodzi o wysokiej plastyczności złącza,

- Próba udarności została przeprowadzona w temperaturze $-60{ }^{\circ} \mathrm{C}$. Próbki były przygotowane wg standardu DNV-0S-C401. Przy próbie udarności wymagana praca łamania wynosi minimum 46J. Wszystkie próbki wykazały dużo większą pracę łamania niż była wymagana dla tej stali.

- Badania makroskopowe zostały przeprowadzone na przekroju poprzecznym próbki. Po wykonaniu zgładu próbka cechowała się dobrym wtopieniem a także prawidłowym kształtem geometrycznym spoiny. W próbce nie stwierdzono żadnych niezgodności spawalniczych,

- Badanie twardości złącza próbnego wg standardu DNV-OS-C401 w górnej i dolnej linii wtopienia nie przekroczyły maksymalnej twardości $420 \mathrm{HV}$. W strefie wpływu ciepła (SWC), nie doszło do zbyt dużego zahartowania, co mogłoby być przyczyną pęknięć zimnych, ani zbyt dużego zmiękczenia spoiny, co wskazywałoby na przegrzanie złącza i obniżenie własności wytrzymałościowych w obszarze złącza,

- Wszystkie badania mechaniczne, a w szczególności badanie udarności w potwierdzają wysoką jakość złącza oraz jego bardzo dobre własności mechaniczne.

- Właściwie przygotowany pWPS oraz starannie przygotowana płyta próbna a także prawidłowo prowadzona kontrola wstępna i bieżąca pozwoliły na wykonanie poprawnego złącza.

Po zakończeniu wszystkich czynności związanych z kwalifikowaniem technologii spawania uzyskano zakres uprawnień na wykonywanie spoin o grubościach materiału podstawowego 20 $\div 80 \mathrm{~mm}$. Zakres kwalifikacji dla blach obejmuje również rury o zewnętrznej średnicy większej niż $500 \mathrm{~mm}$.

\section{Podsumowanie}

Po przeprowadzeniu wszystkich badań wg. standardu DNV-OS-C401 oraz analiz wyników sformułowano następujące wnioski:

- Opracowana technologia spawania stali WELDOX 700 oraz badania przeprowadzone na złączu próbnym, pozwala w szerokim zakresie na wykonywanie konstrukcji stalowych typu: offshore,

- Badania nieniszczące przeprowadzone na złączu spawanym nie wykazały żadnych niezgodności powierzchniowych ani objętościowych, zwłaszcza obecności pęknięć typu zimnego stanowiących największe zagrożenie podczas spawania tego typu stali,

- Przeprowadzone badania niszczące, wykazały, iż złącze próbne zostało wykonane poprawnie. Potwierdzają to wyniki badań, które zostały przedstawione w pracy. W rezultacie badania mechaniczne potwierdzają poprawność opracowania technologii spawania stali WELDOX 700,

- W przypadku procedury wg standardu DNV-OS-C401 w bardzo prosty sposób rozszerzono kwalifikację o EN ISO 15614-1,

- Doświadczenia zdobyte w trakcie procedury kwalifikowania technologii spawania wpływają na poprawę, jakości wytwarzanych konstrukcji, a także na niższe koszty produkcji.

\section{Literatura}

[1] Pakos R., Romek E.: Konstrukcje stalowe pełnomorskie (offshore) - rodzaje, remonty. Przegląd Spawalnictwa 2009, nr 1, str.3-11.

[2] Brózda J.:Stale konstrukcyjne i ich spawalność. Instytut Spawalnictwa, Gliwice 2009.

[3] Lachowicz M., Nosko W.: Spawanie stali konstrukcyjnej WELDOX 700. Przegląd Spawalnictwa 2010, nr 1, str.13-19.
[4] Saperski M.: Procedura kwalifikowania technologii spawania konstrukcji offshore według przepisów DNV. Biuletyn Instytutu Spawalnictwa 2010, nr 6, str.57-63.

[5] https://rules.dnvgl.com/.../downloadPDF.asp?...dnvgl Offshore Standard DNV-OS- B101"Metallic Materials", October 2012 data pobrania: 03.12.2015. 